\title{
PERBANDINGAN ALGORITMA SHORTEST PATH DALAM PEMROSESAN CITRA DIGITAL SEAM CARVING
}

\author{
F. Alvin Sebastian ${ }^{1}$ \\ R. Gunawan Santosa ${ }^{2}$ \\ Theresia Herlina R. ${ }^{3}$ \\ florentinus.alvin@ti.ukdw.ac.id \\ gunawan@staff.ukdw.ac.id \\ herlina@staff.ukdw.ac.id
}

\begin{abstract}
Seam carving is a method of content aware image resizing. As solutions shortest path algorithms are used to find images seams. Seam is a horizontal or vertical path of animage that has minimum energy. There are two (2) shortest path algorithms that will be discussed in this paper. This paper contains the results of shortest path algorithms comparison between Dijkstra and Directed Acyclic Graph to see which one is better than another in case of efficiency. The precomputed and recomputed methods will be compared to find the more efficient method for executing the seam carving transformation. A web application has been built for this purpose. This web app is capable of transforming image size with seam carving method. The complexity of Dijkstra and Acyclic will be compared to find which one is better. The result is Dijkstra has been won, with the $O(4 \mathrm{~V})$ with Acyclicis $O(5 \mathrm{~V})$. The use of precomputed and recomputed is evaluated by the conditions. If the preparation is evaluated then recomputed is more efficient, but if the preparation is not evaluated then the precomputed method is the better one and has faster performance.
\end{abstract}

Keywords: seam carving, shortest path, minimum energy, gradient magnitude, perbandingan algoritma, Dijkstra, acyclic

\section{Pendahuluan}

Image scaling dan cropping merupakan metode yang kerap dipakai dalam melakukan image resizing atau pengubahan ukuran citra. Sebagian besar metode yang digunakan adalah scaling. Scaling merupakan pengubahan ukuran citra berdasarkan skala tanpa mempertimbangkan proporsi panjang dan lebarnya. Scaling juga tidak mempertimbangkan isi dari citra. Cropping terbatas karena hanya menghilangkan piksel pada citra dalam batasan area tertentu saja. Image Resizing yang lebih efektif dapat dicapai dengan mempertimbangkan isi dari citra dan bukan hanya batasan geometri saja (Avidan \& Shamir, 2007).

Seam carving adalah sebuah metode untuk mengubah ukuran citra dalam pengolahan citra digital yang memperhatikan dan mempertimbangkan obyek yang terdapat dalam citra tersebut. Secara garis besar, proses pengolahan citra digital ini akan mencari bagian yang kurang penting dari citra berupa rute piksel (path of pixels) dan menghapusnya untuk mengecilkan ukuran citra atau menduplikasinya untuk memperbesar ukuran citra. Rute piksel yang kurang penting merupakan rute piksel dengan energi yang paling kecil. Rute piksel bisa didapatkan dari atas sampai bawah citra untuk mengubah panjang citra atau dari kiri ke kanan untuk mengubah tinggi citra. Proses untuk menentukan rute piksel atau seam akan diterangkan pada bagian landasan teori.

Algoritma untuk menentukan seam mana yang akan diproses yaitu Dijkstra dan Acyclic Vertex -Weighted Graph. Penelitian ini mengimplementasikan algoritma Dijkstra dan Acyclic Vertex -Weighted dalam memproses citra digital dan membandingkan algoritma-algoritma tersebut untuk mencari algoritma yang efisien. Penelitian ini juga akan membahas mengenai perbandingan antara pre-computed seams dan recomputed seam. Pre-computed seam disini didefinisikan sebagai pemakaian struktur data yang digunakan untuk menyimpan seams of energy. Recomputed adalah sistem akan mencari ulang seam baru untuk diproses. Jadi untuk recomputed sistem akan melakukan pencarian seam setiap kali ia melakukan proses resize.

\footnotetext{
${ }^{1}$ Program Studi Teknik Informatika, Universitas Kristen Duta Wacana, Yogyakarta

${ }^{2}$ Program Studi Teknik Informatika, Universitas Kristen Duta Wacana, Yogyakarta

${ }^{3}$ Program Studi Teknik Informatika, Universitas Kristen Duta Wacana, Yogyakarta
} 
Menurut Low (1991) dan Teuber (1993), seam carving merupakan bagian dari pengolahan citra dan pemrosesan sinyal digital yang mempertahankan sifat penting pada obyek dalam suatu citra digital. Beberapa penelitian yang berhubungan dengan seam carving adalah Sarkar, Nataraj, dan Manjunath (2009) yang melakukan deteksi seam carving dan lokalisasinya. Sedangkan Thilagam dan Karthikeyan (2012) melakukan optimisasi ukuran citra dengan menggunakan piece seam carving.

Sedangkan pada penelitian ini akan dilihat perbandingan kompleksitas antara algoritma Djikstra dan Acyclic pada proses pencarian seam-seam yang mempunyai energi rendah. Metodologi penelitian dalam perbandingan kompleksitas dilakukan dengan menganalisis program dan peseudocode dari kedua algoritma tersebut sebab perbandingan pengamatan secara visual dari kedua algoritma tersebut sukar dilakukan.

\section{Tujuan dan Manfaat Penelitian}

Tujuan utama dari penelitian ini adalah untuk mengetahui hasil perbandingan implementasi algoritma shortest path Dijkstra dan Acylic Vertex Weighted dalam pemrosesan citra digital seam carving serta perbandingan implementasinya dalam pre-computed seams dan recomputed seam, sehingga dapat diperoleh metode yang lebih optimal. Penelitian ini juga bertujuan untuk membuat aplikasi berbasis web yang dapat digunakan sebagai alat pengolah citra digital sesuai dengan konteks penelitian.

\section{Rumusan Masalah}

1) Apakah Algoritma Dijkstra ataukah Acyclic Vertex -Weighted Graph yang lebih baik digunakan dalam proses seam carving dilihat dari kompleksitas algoritma tersebut?

2) Agar performa run-time sistem lebih cepat, diantara precomputed seams dan recomputed seam metode apakah yang lebih efisien untuk diimplementasikan?

\section{Hipotesis}

Ada dua hal yang menjadi hipotesis penulis perihal kompleksitas algoritma, hipotesis penulis adalah Acyclic Vertex Weighted Graph akan memiliki algoritma yang lebih kompleks karena algoritma tersebut akan mencari topological order terlebih dahulu sebelum melakukan proses pencarian shortest path. Adapun keterangan lebih lanjut mengenai topological order dapat dilihat dalam bagian 5.4 dalam landasan teori.

Dalam perbandingan precomputed seams dan recomputed seam, penulis memiliki hipotesis bahwa precomputed seams akan memiliki performa yang lebih cepat dibandingkan recomputed seams. Alasannya adalah karena precomputed seam akan mencari dan mensortir seam-seam yang akan digunakan sebagai acuan dalam melakukan resize sehingga tidak perlu melakukan pencarian ulang shortest path karena tiap seam sudah disimpan dalam sebuah struktur data yang akan disediakan untuk prosesini.

\section{Landasan Teori}

\subsection{Seam Carving}

Menurut penemunya yaitu Avidan dan Shamir (2007) seam carving adalah sebuah operator citra yang melakukan resize, baik itu mengecilkan atau membesarkan citra, dengan memperhatikan isi dari citra tersebut. Tujuan seam carving adalah mendapatkan sebuah citra berukuran baru dengan obyek yang menonjol dalam citra dalam citra masih jelas atau bahkan tidak terpengaruh oleh proses resize. Artinya dalam proses ini, identifikasi obyek merupakan hal yang vital. Seam sendiri adalah 8 connected-path yang optimal dari piksel-piksel dalam sebuah citra yang diambil dari atas ke bawah atau dari kiri ke kanan, dimana keoptimalan ditentukan oleh fungsi energi citra (Avidan \& Shamir, 2007). Energi yang digunakan sebagai acuan dalam seam carving didapatkan dengan metode gradient magnitude. Citra akan dikonversi menjadi sebuah graf yang memiliki bobot yang berupa bilangan energi terebut. Untuk mencari seam dengan bobot terendah akan digunakan algoritma shortest path Djikstra dan Acyclic Vertex Weighted Graph. 
Setelah seam didapatkan maka seam tersebut digunakan sebagai acuan untuk menghilangkan atau menduplikasi piksel-piksel untuk proses resize. Menghilangkan jika akan mengecilkan ukuran citra. Menduplikasi jika akan membesarkan ukuran citra. Setelah itu proses diulangi hingga didapatkan ukuran citra yang diinginkan.

\subsection{Gradient Magnitude}

Berdasarkan catatan dari David (2005), gradient dari sebuah citra mengukur perubahan dari citra. Perubahan tersebut memberikan dua macam informasi. Gradient magnitude dari tiap piksel akan disimpan dalam sebuah vector untuk kemudian dikomputasikan sebagai bobot dari graf. Gradient magnitude dapat diperoleh dengan rumus:

$$
I(x, y)=\sqrt{d x^{2}+d y^{2}}
$$

Dalam persamaan tersebut $\mathrm{dx}$ merupakan perubahan nilai grayscale piksel dengan arah $\mathrm{x}$ (horizontal), sedangkan dy perubahan pada arah y (vertikal). Sedangkan untuk mendapatkan nilai grayscale dari sebuah piksel citra RGB digunakan rumus luminosity:

$$
I(r, g, b)=(0.2126 \times r)+(0.7152 \times g)+(0.0722 \times b)
$$

Rumus diatas akan dipakai untuk mendapatkan nilai grayscale yang digunakan untuk menghitung $\mathrm{dx}$ dan dy. Setelah nilai grayscale didapatkan, dx dan dy dapat diperoleh dengan rumus berikut:

$$
\begin{aligned}
& d x=I(x-1, y)-I(x+1, y) \\
& d y=I(x, y-1)-I(x, y+1)
\end{aligned}
$$

Dalam persamaan tersebut dapat dilihat bahwa nilai dx dari piksel $\mathrm{I}(\mathrm{x}, \mathrm{y})$ didapatkan dari nilai gradient piksel $\mathrm{I}(\mathrm{x}-1, \mathrm{y})$ yaitu piksel di sebelah kirinya dan dikurangi dengan gradient piksel di sebelah kanannya yaitu $\mathrm{I}(\mathrm{x}+1, \mathrm{y})$. Nilai dari dy didapatkan dengan mengurangkan piksel di atasnya (I(x,y-1)) dan piksel di bawahnya (I(x, y+1)). Gambar 1 ini merupakan contoh gradient magnitude citra:

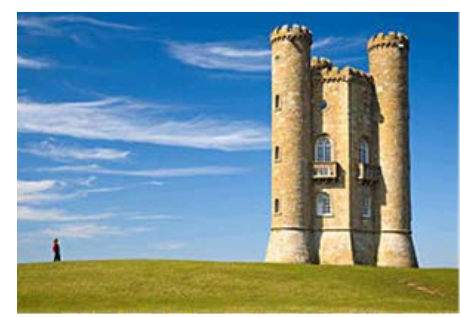

(a)

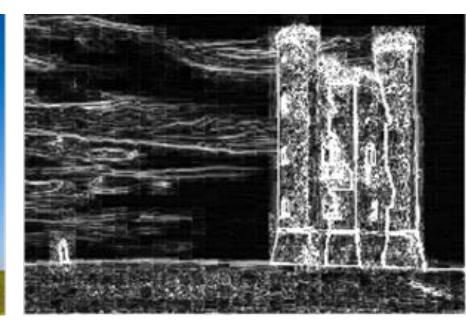

(b)

Gambar 1. (a) Gambar citra asli, (b) Gambar citra yang dikonversi menjadi citra gradient magnitude.

\subsection{Dijkstra}

Algoritma Dijkstra ditemukan oleh Edsger Dijkstra pada tahun 1956 dan dipublikasikan pada tahun 1959. Menurut Even (2011), algoritma Dijkstra ini adalah algoritma yang mirip dengan algoritma Prim's tetapi digunakan untuk menghitung Shortest Path Tree (SPT). Sebagai algoritma shortest path algoritma ini sering dipakai untuk memecahkan masalah minimalisasi. Gambar 2 di bawah ini merupakan bagan pseudocode untuk algoritma Dijkstra: 


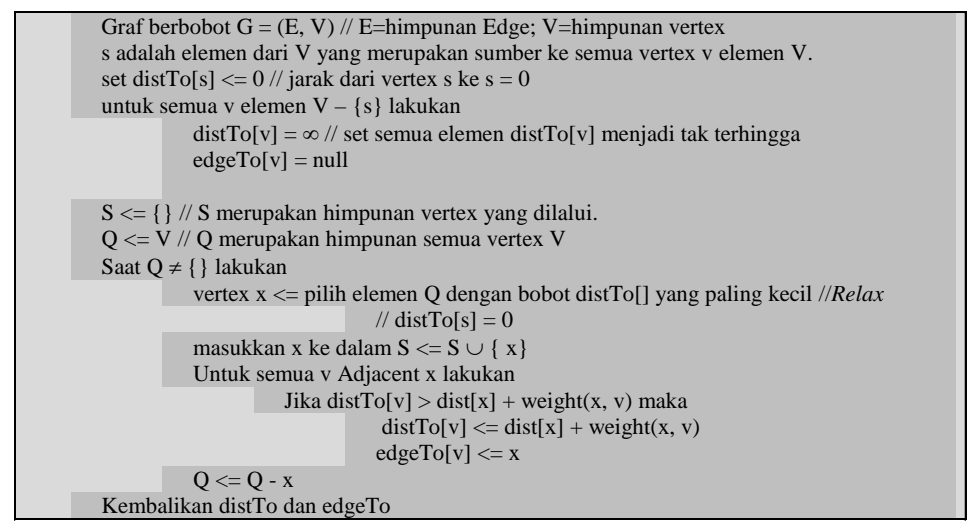

Gambar 2. Bagan pesudocode Algoritma Dijkstra

Dalam pseudocode tersebut dijelaskan bahwa langkah pertama adalah menyediakan sebuah graf berbobot $\mathrm{G}$ dengan $\mathrm{E}$ yang merupakan himpunan edge, dan $\mathrm{V}$ merupakan himpunan vertex. Variabel s merupakan starting point atau sumber ke semua vertex $\mathrm{v}$ dalam elemen V. Vektor distTo[v] merupakan vector yang digunakan untuk menyimpan jarak terpendek menuju vertex $\mathrm{v}$. edgeTo[v] adalah edge yang menuju $\mathrm{v}$ dengan jarak terpendek.distTo[v] untuk setiap vertex $\mathrm{v}$ bernilai tak terhingga, supaya dapat dibandingkan dengan jarak yang lebih pendek.

\subsection{Acyclic}

Tidak jauh berbeda dengan Dijkstra, menurut Even (1979) metode ini mencari shortest path dengan mengunjungi tiap vertex $\mathrm{x}$ yang ada dan mencari nilai distTo[v] dan edgeTo[v], $\mathrm{v}$ merupakan tetangga dari x. Perbedaan algoritma ini dengan Dijkstra yaitu algoritma ini mengunjungi setiap vertex dengan secara topological order. Artinya sebelum proses pencarian shortest path, sistem akan mencari terlebih dahulu topological order dari graf tersebut yang kemudian dijadikan acuan dalam mengunjungi tiap vertex yang ada. Gambar 3 di bawah ini merupakan bagan pseudocode untuk algoritma mendapatkan topological order:

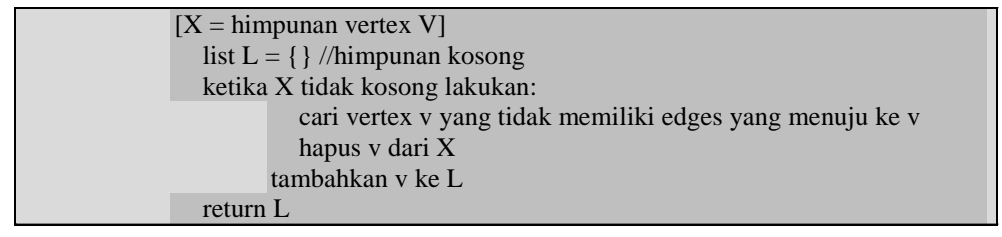

Gambar 3. Bagan pesudocode Algoritma topological order

Untuk mendapatkan topological order L yang yang perlu dilakukan adalah dengan memencari vertex $\mathrm{v}$ dalam vector $\mathrm{X}$ yang tidak memiliki edge yang menuju ke dirinya, dan kemudian memasukkan $\mathrm{v}$ tersebut ke dalam topological order L. L akan digunakan sebagai acuan urutan vertex yang akan diproses dalam proses pencarian shortest path.

Setelah urutan topological L didapatkan, maka lakukan pencarian shortest path hanya saja pada $\mathrm{Q}<=\mathrm{V}$ diganti dengan $\mathrm{Q}=\mathrm{L}$. Algoritma ini akan menggunakan vector $\mathrm{L}$ yang merupakan topological order dalam melakukan proses relax untuk setiap elemen dalam vector tersebut. Kembalian dari proses dalam pseudocode tersebut adalah vector distTo dan vector edgeTo.

\subsection{Precomputed dan Recomputed}

Precomputed seams adalah sebuah metode yang menggunakan sebuah struktur data yang menyimpan seams yang ditemukan. Artinya sebelum proses transformasi citra 
dilakukan, sistem sudah terlebih dahulu mencari dan menyimpan seams yang digunakan sebagai acuan dari proses transformasi citra. Sedangkan recomputed seam adalah sebuah metode yang hanya akan mencari seam sesuai dengan kebutuhan proses transformasi. Dalam recomputed seam, sistem akan melakukan proses pencarian dan resize dalam waktu yang bersamaan. Berikut ini merupakan bagan flowchart untuk metode precomputed:

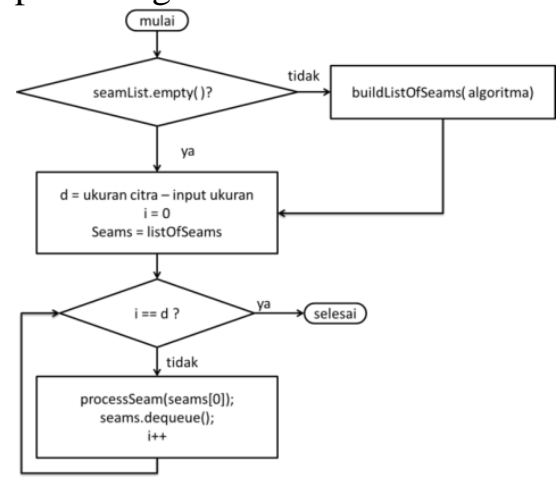

Gambar 4. Flowchart precomputed seams

Proses precomputed yang terdapat pada Gambar 4 diawali dengan pengecekan listOfSeams. Jika listOfSeams kosong maka proses akan melakukan pembentukan listOfSeams. Setelah pembentukan selesai, maka akan dilanjutkan dengan pemrosesan listOfSeams yang sudah dibangun terhadap citra. Variabel d merupakan jumlah perubahan ukuran citra. Berikut ini merupakan flowchart untuk algoritma recomputed:

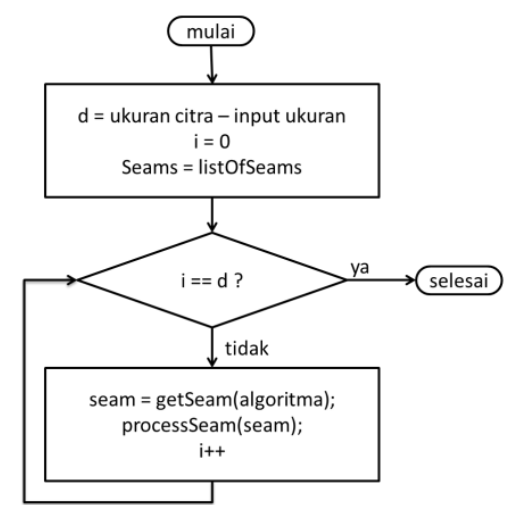

Gambar 5. Flowchart proses recomputed seam

Untuk proses recomputed yang tertuang pada Gambar 5, sistem akan melakukan perulangan sebanyak $d$ kali. Perulangan tersebut digunakan untuk mencari seam berdasarkan algoritma yang dipakai dan kemudian memproses seam tersebut terhadap citra.

\section{Hasil Penelitian}

\subsection{Perbandingan Kompleksitas Algoritma Dijkstra dan Acyclic}

Untuk membandingkan efisiensi algoritma digunakan perbandingan kompleksitas algoritma tersebut yang didasarkan pada Gacs dan Lovasz (1999). Gambar 6 merupakan potongan code algoritma Dijkstra yang diimplementasikan di dalam sistem: 


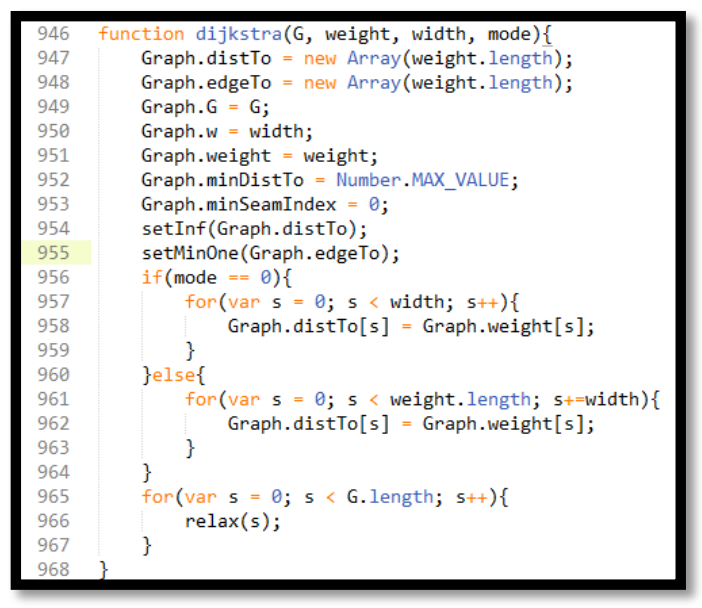

Gambar 6. Potongan code Dijsktra

Dalam potongan code di atas V adalah G.length pada baris 965 dan W merupakan width dalam parameter fungsi tersebut. Nilai 3 didapatkan dari proses relax() yang dalam konteks ini hanya akan memproses maksimal 3 vertex. Dijkstra sendiri memiliki worst case $\mathrm{O}\left(|\mathrm{V}|^{2}\right)$ ketika jumlah edge adalah semua elemen lainnya. Namun dalam sistem ini performa algoritma Dijkstra adalah $\mathrm{O}(3 \mathrm{~V}+\mathrm{W})$. Berikut ini adalah gambar tiap vertex dalam vector 3 x 3

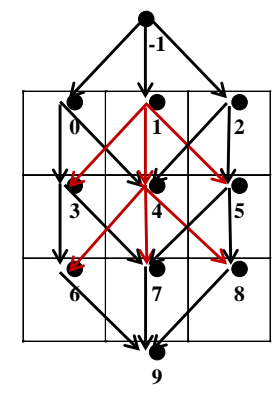

Gambar 7. Gambar ilustrasi vertex dan edge dalam graf vector citra

Dari Gambar 7 dapat disimpulkan bahwa maksimal tiap vertex memiliki tiga (3) edge (garis panah merah). Berarti jika algoritma Dijkstra dijalankan, maka ketika tiap vertex i dilalui, algoritma akan memproses maksimal tiga (3) vertex yang adjacent dengan vertex i. Dengan begitu didapatkan kompleksitas Dijkstra dalam konteks sistem ini adalah $\mathrm{O}(3 \mathrm{~V}+$ $\mathrm{W})$. Kondisi terburuk adalah $\mathrm{W}=\mathrm{V}$ sehingga algoritma ini bisa memiliki kompleksitas $\mathrm{O}(4 \mathrm{~V})$ atau dapat dinotasikan dengan $\mathrm{O}(\mathrm{V})$ yang merupakan kompleksitas dengan kecepatan linear.

Dalam implementasi dalam sistem algoritma ini memiliki kompleksitas yang hampir sama dengan algoritma Dijkstra. Berbeda dengan algoritma Dijkstra, algoritma ini memerlukan proses sort yang memilki kompleksitas $\mathrm{O}(\mathrm{V})$ karena dalam implementasinya dalam menentukan vertex yang terlebih dahulu dikerjakan tidak perlu membandingkan, hanya memasukkan index dari vertex secara horizontal atau vertical dengan perhitungan modulus dengan acuan $\mathrm{W}$ atau width dari citra. Berikut ini merupakan potongan code untuk menentukan topological order: 


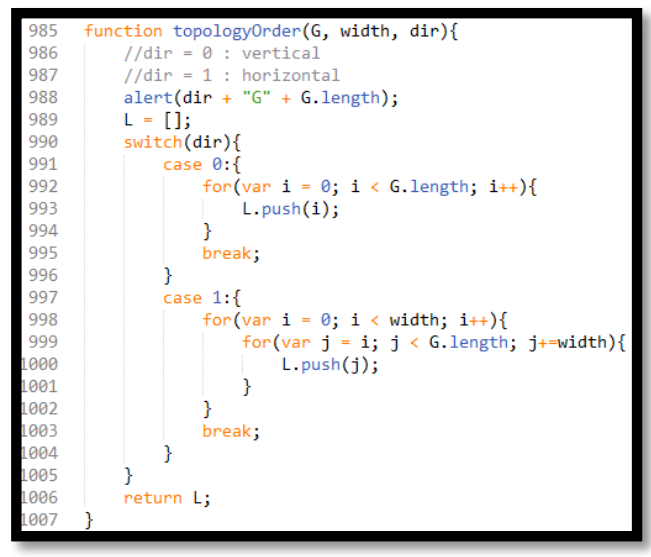

Gambar 8. Potongan code fungsi topologyOrder

Pada Gambar 8, V dalam fungsi ini adalah G.length (baris 992 dan 999) yang merupakan jumlah elemen dari graf dan juga jumlah elemen vector citra. Dalam potongan code tersebut perulangan dilakukan selama V kali, sehingga di dapatkan waktu T(V). Berikut ini adalah potongan code fungsi acyclic untuk mencari shortest path dalam graf:

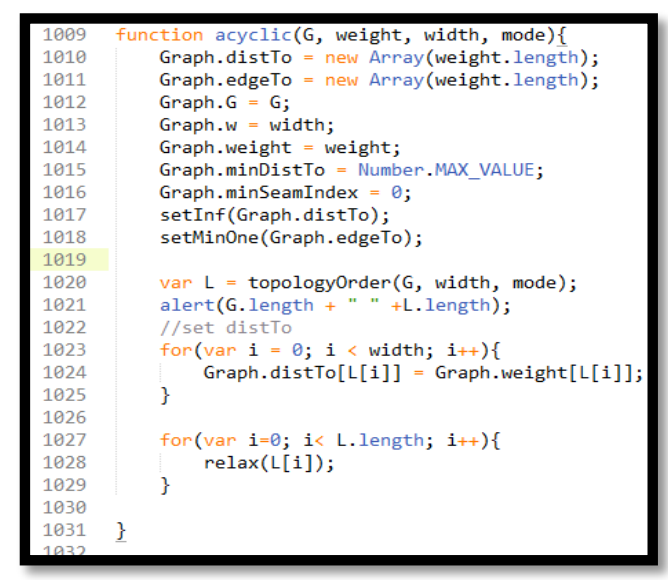

Gambar 9. Potongan code fungsi acyclic.

Dari potongan code pada Gambar 9, L.length merupakan yang memiliki nilai sama dengan jumlah elemen vector citra sehingga didapatkan $\mathrm{T}(\mathrm{W}+3 \mathrm{~V})+\mathrm{T}(\mathrm{V})$ atau $\mathrm{O}(\mathrm{W}+4 \mathrm{~V})$ dengan $\mathrm{W}$ adalah width yang merupakan parameter (baris 1009) dan $\mathrm{T}(\mathrm{V})$ adalah pemanggilan fungsi topologyOrder pada baris ke 1020. Dengan kondisi terburuk $\mathrm{W}=\mathrm{V}$, maka bisa kompleksitas ini bisa dinotasikan dengan $\mathrm{O}(5 \mathrm{~V})$ atau $\mathrm{O}(\mathrm{V})$.

Dalam konteks running time kedua algoritma ini, Dijkstra dan Acyclic memiliki kompleksitas yang sama yaitu $\mathrm{O}(\mathrm{V})$. Akan tetapi jika membandingkan running time sebelum notasi $\mathrm{O}(\mathrm{V})$ didapatkan maka algoritma Acyclic memiliki running time yang lebih lama dibandingkan Dijkstra yaitu $\mathrm{O}(5 \mathrm{~V})$ dibanding $\mathrm{O}(4 \mathrm{~V})$. Hal ini disebabkan karena dalam prosesnya, algoritma Acyclic harus membentuk topological order untuk menentukan urutan vertex yang diproses. Artinya algoritma Dijkstra memiliki running time yang lebih cepat daripada Acyclic.

Mengenai hasil seam dari algoritma Dijkstra dan Acyclic ditemukan bahwa seam yang didapatkan bisa berbeda, karena urutan vertex yang diproses berbeda. Hal ini dimungkinkan terjadi ketika ditemukan vertex -vertex yang memiliki energi yang sama, sehingga urutan pemrosesan akan mempengaruhi hasilnya juga. 


\section{F. Alvin Sebastian, R. Gunawan Santosa, Theresia Herlina R.}

\subsection{Perbandingan Kompleksitas Precomputed dan Recomputed}

Metode precomputed hanya dapat berjalan ketika semua seams vertical atau horizontal sudah tersimpan di dalam struktur data list of seams. List of seams berisi seam yang didapatkan dengan proses shortest path. Dalam sistem, list of vertical seams dinamakan dengan vseams dan hseams untuk horizontal seams. Karena proses membangun list of seams juga termasuk dalam proses ini, maka kompleksitas untuk proses membangun seams juga akan dimasukkan ke dalam proses ini. Gambar 10 berikut ini merupakan potongan code untuk membangun list of seam:

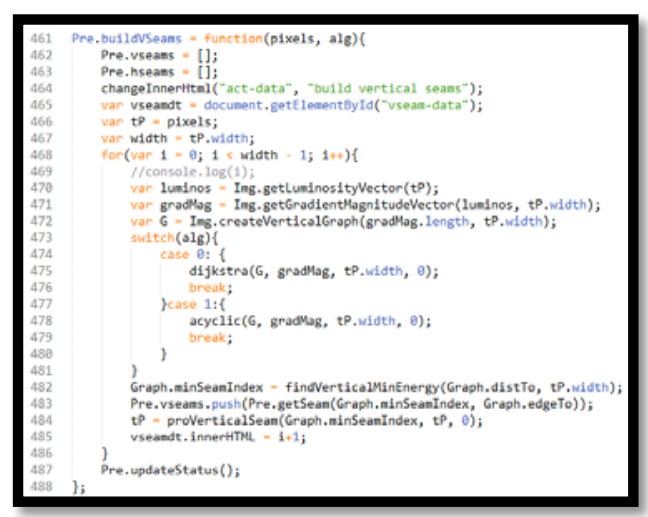

Gambar 10. Potongan code untuk fungsi buildVSeams

V merupakan panjang citra yang berada dalam G.length. W merupakan panjang citra (width) yang didapatkan dari tP.width (baris 467 ). tP merupakan sebuah object ImageData. Jika $\mathrm{V}$ adalah jumlah element dalam vector citra dan $\mathrm{W}$ adalah panjang citra maka untuk membangun list of seams diperlukan waktu T(W . V) dimana V merupakan kompleksitas dari algoritma shortest path yang dipakai. Bisa dikatakan bahwa kompleksitas didapatkan dari pemrosesan algoritma $\mathrm{O}(\mathrm{V})$ sebanyak $\mathrm{W}$ kali (baris 468). Dengan kondisi terburuk $\mathrm{W}=\mathrm{V}$ maka kompleksitas dalam proses pembangunan list of seams dibutuhkan waktu $\mathrm{O}\left(\mathrm{V}^{2}\right)$.

Untuk memproses seams diperlukan input dw yang merupakan jumlah seam yang di akan diproses. Gambar 11, merupakan fungsi pemrosesan seam untuk precomputed:

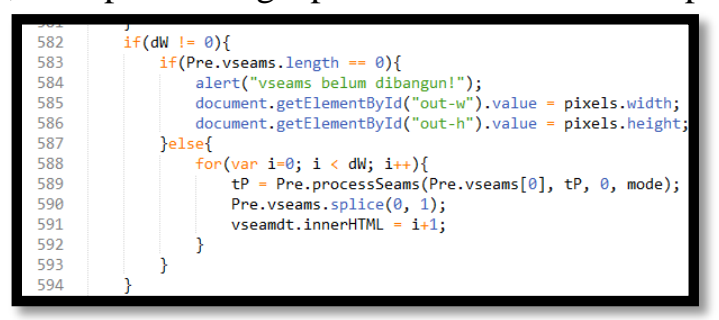

Gambar 11. Potongan code fungsi precomputed

Jika panjang seam adalah $\mathrm{W}$ maka pemrosesan seam terhadap image memiliki kompleksitas waktu $\mathrm{T}(\mathrm{dw} \cdot \mathrm{W})$. Nilai $\mathrm{W}$ didapatkan dari potongan code pemrosesan seam pada baris 589 (fungsi Pre.processSeams). Gambar 12 merupakan potongan code fungsi Pre.processSeams yang melakukan perulangan selama W kali: 


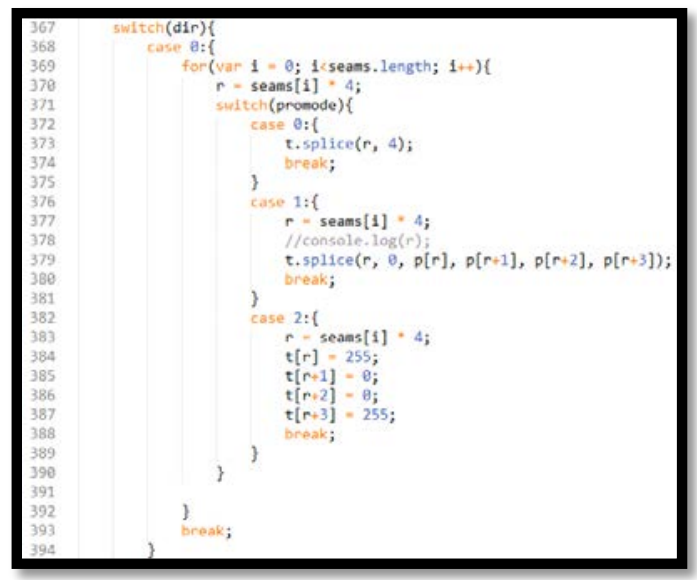

Gambar 12. Potongan code fungsi Pre.processSeams

Nilai W didapatkan dari seams.length yang merupakan panjang dari seam sehingga total kompleksitas yang didapatkan adalah $\mathrm{T}(\mathrm{WV}+\mathrm{dw} \cdot \mathrm{W})$. Dengan kondisi terburuk yaitu $\mathrm{W}=\mathrm{V}$ dan $\mathrm{dw}=\mathrm{W}=\mathrm{V}$ maka kompleksitas Algoritma tersebut bisa menjadi $\mathrm{O}\left(\mathrm{V}^{2}+\mathrm{V}^{2}\right)$ menjadi $\mathrm{O}\left(2 \mathrm{~V}^{2}\right)$ atau $\mathrm{O}\left(\mathrm{V}^{2}\right)$. Kondisi tersebut ketika precomputed hanya mengerjakan satu (1) kali eksekusi saja.

Metode recomputed pada Gambar 13, tidak membutuhkan struktur data tambahan. Artinya kompleksitas ditentukan oleh dw dan kompleksitas algoritma terhadap citra. Gambar 13 ini merupakan potongan code untuk metode precomputed:

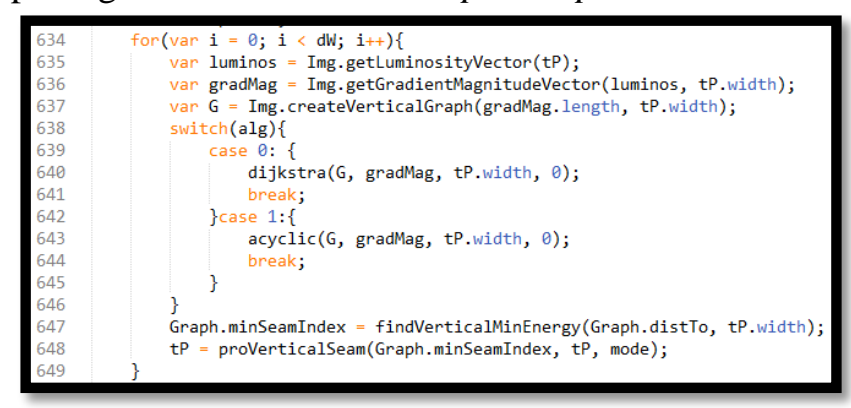

Gambar 13. Potongan kode metode recomputed

Kompleksitas yang didapatkan untuk metode recomputed adalah $\mathrm{T}(\mathrm{dw} \times \mathrm{V})$ dimana (V) merupakan kompleksitas dari algoritma Dijkstra maupun Acyclic dan dW adalah jumlah perulangan dilakukan sebanyak dW (baris 634 ). Sehingga didapatkan $\mathrm{T}(\mathrm{dw} \cdot \mathrm{V})$ ), untuk kasus terburuk $\mathrm{dw}=\mathrm{W}=\mathrm{V}$ maka algoritma tersebut memiliki kompleksitas $\mathrm{O}\left(\mathrm{V}^{2}\right)$.

Menurut Sedgewick dan Wayne (2011) untuk mengerjakan sebuah task yang sama metode precomputed pasti akan memiliki waktu yang lebih lama dengan running time $\mathrm{O}\left(2 \mathrm{~V}^{2}\right)$ dibandingkan dengan recomputed yang memiliki running time $\mathrm{O}\left(\mathrm{V}^{2}\right)$. Untuk resize berikutnya, metode ini hanya membutuhkan waktu $\mathrm{O}(\mathrm{V})$ saja, sehingga metode ini tepat untuk proses melakukan resize berulang ulang. Sedangkan untuk recomputed tetap membutuhkan waktu $\mathrm{O}\left(\mathrm{V}^{2}\right)$.

Tabel 1 berikut ini merupakan hasil dari pemrosesan citra sampel dalam ukuran $240 \times$ 160 px dengan perubahan sebanyak 20 pixel sampai dengan $120 \times 120$ px: 
Tabel 1.

Tabel hasil pemrosesan seam carving

\begin{tabular}{|c|c|c|}
\hline No & Citra & Data \\
\hline 0 & & Tidak ada \\
\hline 1 & & $\begin{array}{l}\text { Action: Seam Carving } \\
\text { Algorithm: Acyclic } \\
\text { Method: Recomputed } \\
\text { VSeam(s) processed: } 20 \\
\text { HSeam(s) processed: } 0 \\
\text { Execution Time: } 1.262 \mathrm{sec}\end{array}$ \\
\hline 2 & & $\begin{array}{l}\text { Action: Seam Carving } \\
\text { Algorithm: Acyclic } \\
\text { Method: Recomputed } \\
\text { VSeam(s) processed: } 20 \\
\text { HSeam(s) processed: } 20 \\
\text { Execution Time: } 4.003 \mathrm{sec}\end{array}$ \\
\hline 3 & & $\begin{array}{l}\text { Action: Seam Carving } \\
\text { Algorithm: Acyclic } \\
\text { Method: Recomputed } \\
\text { VSeam(s) processed: } 20 \\
\text { HSeam(s) processed: } 0 \\
\text { Execution Time: } 1.844 \text { sec }\end{array}$ \\
\hline 4 & & $\begin{array}{l}\text { Action: Seam Carving } \\
\text { Algorithm: Acyclic } \\
\text { Method: Recomputed } \\
\text { VSeam(s) processed: } 20 \\
\text { HSeam(s) processed: } 20 \\
\text { Execution Time: } 3.233 \text { sec }\end{array}$ \\
\hline 5 & & $\begin{array}{l}\text { Action: Seam Carving } \\
\text { Algorithm: Acyclic } \\
\text { Method: Recomputed } \\
\text { VSeam(s) processed: } 20 \\
\text { HSeam(s) processed: } 0 \\
\text { Execution Time: } 0.801 \mathrm{sec}\end{array}$ \\
\hline
\end{tabular}

Dari Tabel 1 tersebut dapat dilihat bahwa sampel memiliki batas optimal pada perubahan ukuran ke 4, karena pada perubahan ke 5 terlihat bahwa bagian leher jerapah terpotong. Hal ini dapat terjadi melihat bagian yang dilindungi dari citra ini adalah bagian badan jerapah yang cenderung memiliki energi gradient magnitude yang besar. Bagian leher dan kepala dari jerapah dapat dilindungi dengan cara memberikan energi yang lebih besar pada daerah tersebut. Dari hasil tersebut juga dapat dilihat bahwa ukuran badan jerapah tidak mengalami perubahan, perubahan yang banyak terjadi adalah mengecilnya background. Dengan demikian proses seam carving ini berhasil melakukan transformasi ukuran citra secara content aware dengan 1 objek didalamnya. 


\section{Kesimpulan}

Berdasarkan hasil penelitian di atas, algoritma Dijkstra memiliki kompleksitas yang lebih kecil yaitu $\mathrm{O}(4 \mathrm{~V})$ dibandingkan Acyclic yang memiliki kompleksitas waktu $\mathrm{O}(5 \mathrm{~V})$. Artinya algoritma Dijkstra memiliki performa yang lebih cepat dibandingkan dengan Acyclic meskipun pada dasarnya notasi Big Oh kedua algoritma ini sama yaitu $\mathrm{O}(\mathrm{V})$.

Efisiensi metode precomputed dam recomputed tergantung pada konteks pemakaiannya, meskipun sama-sama mempunyai kompleksitas $\mathrm{O}\left(\mathrm{V}^{2}\right)$. Jika proses mempertimbangkan proses awal atau hanya dilakukan sekali transformasi saja, metode recomputed lebih efisien, sedangkan jika proses tidak mempertimbangkkan proses awal dan akan dipakai secara kontinyu, maka metode precomputed lebih efisien.

\section{Saran}

Dalam penelitian ini, penulis menemukan beberapa kendala dalam pembuatan sistem yang dapat menjadi saran untuk penelitian selanjutnya. Berikut ini merupakan poin-poin yang menjadi kendala dalam penelitian:

1) Ketika melakukan pemrosesan citra berukuran besar, jika proses memakan waktu yang terlalu lama browser akan memunculkan dialog unresponsive script. Selain itu, pada waktu pemrosesan citra, proses tersebut tidak dapat di interupsi, sehingga tidak memungkinkan menjalankan proses yang asynchronous seperti menampilkan loading bar atau persentase pemrosesan citra, agar lama selesai proses dapat di estimasikan oleh pengguna. Solusi untuk masalah ini adalah dengan menggunakan multithreading dengan menggunakan ajax atau worker.js.

2) Untuk melindungi bagian citra yang memiliki energi lebih rendah, dapat ditambahkan metode lain untuk hasil citra yang sesuai keinginan pengguna. Metode seperti face detecting dapat digunakan untuk kasus melindungi wajah pada citra foto manusia. Energy coloring secara interaktif juga dapat digunakan untuk menentukan objek yang akan dilindungi atau dihilangkan.

3) Agar performa lebih cepat dapat dicari algoritma shortest path dengan metode lain atau dengan model pemrograman dynamic programming.

\section{Daftar Pustaka}

Avidan, S., \& Shamir, A. (2007). Seam Carving for Content-Aware Image Resizing.

Danziger, P. (n.d.). Big O Notation. Retrieved January 19, 2015, from Department of Computer Science - $\quad$ Ryerson University: http://www.scs.ryerson.ca/ mth110/Handouts/PD/bigO.pdf

David, J. (2005). Image Gradients . Retrieved 4 1, 2014, from http://www.cs.umd.edu/: http://www.cs.umd.edu/ djacobs/CMSC426/ImageGradients.pdf

Even, S. (1979). Graph Algorithms. Rockville, Maryland: Computer Science.

Gacs, P., \& Lovasz, L. (1999). Complexity of Algorithm Lecture Notes.

Low, A. (1991). Introductory Computer Vision and Image Processing. Singapore: McGrawHill Book Company (UK) Limited.

MIT. (n.d.). http://web.mit.edu/16.070/www/lecture/big_o.pdf. Retrieved January 19, 2015, from MIT - Massachusetts Institute of Technology: http://web.mit.edu/16.070/www/lecture/big_o.pdf 
F. Alvin Sebastian, R. Gunawan Santosa, Theresia Herlina R.

Sarkar, A., Nataraj, L., \& Manjunath, B. S. (2009). Detection of Seam Carving and Localization of Seam. Proceedings of the 11th ACM workshop on Multimedia and Security, 107-116.

Sedgewick, R., \& Wayne, K. (2011). Algorithms. Massachusetts: Pearson Education, Inc.

Teuber, J. (1993). Digital Image Processing. Hempstead: Prentice Hall International (UK) Ltd.

Thilagam, K., \& Karthikeyan, S. (2012). Optimized Image Resizing using Piecewise Seam Carving. International Journal of Computer Applications, 24-30. 